\title{
The Growing Salience of Online Vietnamese Nationalism
}

\author{
By Dien Nguyen An Luong
}

\section{EXECUTIVE SUMMARY}

- Vietnamese nationalism has a strong undercurrent of anti-China sentiments, and Vietnam's leaders have regularly tapped into such sentiments to shore up their legitimacy and boost Vietnamese nationalism.

- Over the last decade, the helter-skelter growth of social media has bred new popular actors in Vietnamese cybersphere, who are deeply nationalistic but who pursue entirely different political and social agendas. In sum, they give rise to a new nationalistic narrative, one that paints the Vietnam Communist Party as being often too meek and subservient to China, and calls for drastic reforms to the political system—regime change not excluded—to deal with Chinese threats.

- An examination of prominent cases of online Vietnamese nationalism shows that anti-China sentiments have been a recurrent theme and a consistent trigger. The online nationalistic movements have been mostly instigated by popular figures, with state actors playing a facilitating role in stoking and harnessing them for their own ends.

- Manifestations of online nationalism, especially those centred on anti-China and sovereignty issues, may hold serious consequences, including violence and deadly riots. In some instances, online nationalistic campaigns both galvanize and dissipate relatively quickly once state and popular actors have somehow managed to achieve their aims.

- The growing salience of online Vietnamese nationalism has posed serious challenges and dilemmas for the regime. The authorities have had to encourage nationalistic patriotism without letting Sinophobia spiral out of control or turn against the regime. 



\title{
THE GROWING SALIENCE OF ONLINE VIETNAMESE NATIONALISM
}

\author{
By Dien Nguyen An Luong ${ }^{1}$
}

\section{INTRODUCTION}

A multinational fashion retailer. The prime minister of Singapore. A COVID-19 patient who is the daughter of an ultra-wealthy Vietnamese family. They have all been the targets of online Vietnamese nationalists under different circumstances.

Indeed, recent manifestations of potent online nationalism in Vietnamese cybersphere have forced the authorities to become acutely wary of, sensitive to and even accommodating of it. This marks a significant development in the social media landscape: At the very outset, Vietnam's Internet users turned to social media to mostly challenge the official narrative of the mainstream media and to offer a counternarrative to it. But social media users have also become increasingly vocal and frequent in defending Vietnam's image abroad by flagging content they deem controversial and inappropriate. This dynamic has created complex challenges and dilemmas for the authorities who have at times found it useful to leverage nationalistic sentiments to advance its foreign policy positions and yet have reiterated that the task

\footnotetext{
${ }^{1}$ Dien Nguyen An Luong is Visiting Fellow with the Media, Technology and Society Programme of the ISEAS - Yusof Ishak Institute, Singapore. The author would like to thank Ms Lee Sue-Ann and Dr Le Hong Hiep for their constructive comments and suggestions.
} 
of cracking down on anti-state content in cyberspace has never been more crucial. ${ }^{2}$

This paper seeks to answer these questions: What triggers an online nationalistic backlash in Vietnam? Who are the actors behind such campaigns? What are the tactics and strategies used and what are their end goals? Has nationalist online expression been able to shape Vietnam's foreign and domestic policymaking or has it been shaped by them? Has nationalist online expression influenced discourse in the mainstream media?

The paper lays out key characteristics of Vietnamese nationalism and examines how it has evolved. It then takes a closer look at the emergence of online nationalism and high-profile case studies in an effort to sketch out common themes of online nationalistic narratives. The paper also explores what role the Vietnamese state plays in shaping these narratives and how much influence it wields in controlling and managing online nationalism. It concludes by outlining some major dilemmas facing the authorities if they continue seeking to play the online nationalism card in the future.

\section{HOW VIETNAMESE NATIONALISM EVOLVES AND TAKES OFF ONLINE}

To examine expressions of nationalism in Vietnam, it is useful to look at how such sentiments have panned out in China and put them in a comparative context. The reasons are not hard to fathom: Vietnam is believed to have selectively followed the Chinese model, given how ideologically, politically and economically similar Vietnam's system is to China's. This section draws mainly on past research on Vietnamese nationalism, anti-China sentiments in contemporary Vietnam, and territorial disputes and nationalism by these scholars: Tuong Vu, Nhi

2 Dien Nguyen An Luong, “Cyberspace: Vietnam's Next Propaganda Battleground?”, Fulcrum, 25 February 2021, https://fulcrum.sg/cyberspacevietnams-next-propaganda-battleground/ 
Hoang Thuc Nguyen, Hannah Cotillon and Frances Yaping Wang and Brantly Womack.

As Cotillon points out, given structural similarities between China and Vietnam, societal institutions, regime type and historical consciousness are "central structural characteristics" that have chiefly shaped expressions of nationalism in both countries. ${ }^{3}$ In contemporary China and Vietnam, however, a growing body of evidence also shows how nationalism has merged with geopolitical thinking, and how territorial disputes have been a trigger for such expressions of nationalism. ${ }^{4}$ According to Cotillon, territorial disputes have become a litmus test of national pride for both Chinese and Vietnamese leaders. In other words, people expect their governments to act tough in such disputes; failure to do so could be politically damaging. The nature of Chinese and Vietnamese societal institutions and regime type, as Cotillon sums it up, "has meant that expressions of nationalism, even as far as public protests, are permitted at popular levels and are maintained at governmental levels".

In China and Vietnam-be it at government or popular levels-a nationalist discourse has been taking place with a strongly embedded historical narrative fortified by both top-down and bottom-up construction. ${ }^{5}$ Nationalism has been at the core of the Chinese Communist Party's claim on political power since the days of Mao Zedong's leadership. ${ }^{6}$ Nowhere was this more manifest than in 1991, when China launched the "Patriotic Education Campaign" in the wake of the studentled Tiananmen protests two years earlier. ${ }^{7}$ The key tenet of the campaign

\footnotetext{
${ }^{3}$ Hannah Cotillon, “Territorial Disputes and Nationalism: A Comparative Case Study of China and Vietnam", Journal of Current Southeast Asian Affairs 36, no. 1 (2017): 56.

${ }^{4}$ Ibid., p. 52.

${ }^{5}$ Ibid., p. 54.

${ }^{6}$ Christopher R. Hughes, "Chinese Nationalism in the Global Era”, 2006, http:// www.opendemocracy.net/democracy-china/nationalism_3456.jsp

${ }^{7}$ Channel NewsAsia. “China Wields Patriotic Education to Tame Hong Kong's Rebellious Youth”, 27 November 2020, https://www.channelnewsasia.com/ news/asia/hong-kong-china-education-reform-teachers-patriotism-13645838
} 
was to inoculate Chinese youth against a perceived Western ideological "peaceful evolution" strategy as well as to remind them of their country's "century of humiliation" and the Communist Party's role in crushing foreign powers and restoring national sovereignty. ${ }^{8}$ The World Wide Web did not become a vehicle for nationalism in China until the 1990s, when its Internet users started to bristle at and push back against what they perceived as an anti-China narrative perpetuated in the West. Since then, its "national Internet" has emboldened China to craft increasingly sophisticated state-sponsored campaigns aimed at boosting youth nationalism. ${ }^{9}$

But in Vietnam, a distinct feature of its nationalism is the strong undercurrent of anti-China sentiments. It is so deeply embedded in the Vietnamese psyche that it was even marshalled in nationalistic movements against colonialism and other foreign invaders. As Vu points out: Since the latter part of the nineteenth century to the end of the Vietnam War in 1975, Vietnamese nationalism had been conceptualized simply as anti-colonialism. ${ }^{10}$ During the struggles against the French and Americans in the 1950s and 1960s, Vietnam spearheaded a statesanctioned attempt designed to "desinicize the [Vietnamese] past", featuring the country as a well-established, independent and unique civilization. ${ }^{11}$ The then Democratic Republic of Vietnam government sought to exhaust the pretext of a-thousand-year conflict with China

\footnotetext{
${ }^{8}$ Thomas L. Friedman, "Foreign Affairs: China's Nationalist Tide", New York Times, 13 March 1996, https://www.nytimes.com/1996/03/13/opinion/foreignaffairs-china-s-nationalist-tide.html

${ }^{9}$ Liza Lin, "Xi's China Crafts Campaign to Boost Youth Patriotism”, Wall Street Journal, 30 December 2020, https://www.wsj.com/articles/xi-china-campaignyouth-patriotism-propaganda-11609343255

10 Tuong Vu, "Vietnamese Political Studies and Debates on Vietnamese Nationalism", Journal of Vietnamese Studies 2, no. 2 (2007): 175-230, https:// doi.org/10.1525/vs.2007.2.2.175

${ }^{11}$ Patricia Pelley, “'Barbarians' and 'Younger Brothers:' The Remaking of Race in Postcolonial Vietnam”, Journal of Southeast Asian Studies 29, no. 2 (1998): 374-91.
} 
to shape a historical narrative of Vietnam as a people with unwavering resistance against foreign invaders. This multipronged campaign served various purposes: (i) to gain legitimacy for the Communist leadership; (ii) to enlist grassroots support against the French and Americans; and (iii) to boost nationalism. ${ }^{12}$

Intriguingly, according to Ungar and Pelley, the "ancient Chinese invasion" theme was also employed in anti-America propaganda campaigns in South Vietnam. ${ }^{13}$ Cases in point: Nayan Chanda, a veteran journalist who is the author of the acclaimed postwar history Brother Enemy, recalled that at a time when American warplanes were bombing Hanoi in the 1970s, foreign visitors to Vietnam's national museum were briefed on historical accounts of Chinese occupations. ${ }^{14}$ Noam Chomsky, the leading American political activist and one of the most vociferous critic of America's foreign policies, told me in an email interview years ago that in 1970, during a short hiatus in the US bombing of North Vietnam, he was invited to visit the capital Hanoi and lecture at the Polytechnique University there. Chomsky recalled that the first morning he arrived, he was taken to the war museum to listen to long lectures with dioramas about Vietnamese wars with China many centuries ago. To Chomsky, the message Vietnam looked to ram home could not be clearer: "You [the U.S.] happen to be destroying us now, but you'll leave. China will always be here." 15

12 Nhi Hoang Thuc Nguyen, “Anti-Chinese Sentiment in Contemporary Vietnam: Constructing Nationalism, New Democracy, and the Use of 'the Other'", Undergraduate Student Research Awards 40 (Fall 2017): 4, https:// digitalcommons.trinity.edu/cgi/viewcontent.cgi?article=1040\&context=infol it_usra

${ }^{13}$ E.S. Ungar, "The Struggle over the Chinese Community in Vietnam, 19461986", Pacific Affairs 60, no. 4 (1987): 596-614.

${ }^{14}$ Kishore Mahbubani, “Can Asians Think?”, Media Asia 24, no. 3 (1997): 12327, https://doi.org/10.1080/01296612.1997.11726530

15 Dien Luong, "Why Vietnam Loves the Trans-Pacific Partnership", The Diplomat, 16 March 2016, https://thediplomat.com/2016/03/why-vietnam-lovesthe-trans-pacific-partnership/ 
But still, according to Wang and Womack, Vietnamese authorities have always understood too well that anti-China sentiments are a doubleedged sword, for two major reasons. First, Vietnam "could not afford to adopt officially an anti-China stance,"16 given how important such asymmetric bilateral ties were. The Chinese clout has weighed on various fronts, ranging from Beijing's support in the form of money, weapons and advisors for Hanoi's resistance against French and American invasions during the 1950-70 period to China's economic largesse in contemporary Vietnam. ${ }^{17}$ Second, anti-China sentiments are vulnerable to be hijacked by anti-regime agendas, which clearly manifest in the era of swelling social media. Given that, the onus is on any Vietnamese government to maintain a long-term diplomatic relationship with China. But against that backdrop, as Nguyen observes: The cordial façade of Sino-Vietnamese ties had already begun to crack and crumble during the French and early US colonial era as "internationalism and communist fraternalism gave way to national interests". ${ }^{18}$ According to Nguyen, Vietnamese leaders bristled at the "perceived paternalism of their Chinese advisors, as well as China's growing relationship with the US". Such rifts culminated in the decade-long Third Indochina War between China and Vietnam. It all started in 1979, when China sent an estimated force of 600,000 troops to "teach Vietnam a lesson" for ousting the genocidal Khmer Rouge

16 Frances Yaping Wang and Brantly Womack, "Jawing through Crises: Chinese and Vietnamese Media Strategies in the South China Sea", Journal of Contemporary China 28, no. 119 (2019): 712-28.

17 Tuong Vu, "Southeast Asia's New Nationalism: Causes and Significance", Trans-Regional and -National Studies of Southeast Asia, 1, no. 2 (2013): 259-79.

18 Nhi Hoang Thuc Nguyen, “Anti-Chinese Sentiment in Contemporary Vietnam: Constructing Nationalism, New Democracy, and the Use of 'the Other'", Undergraduate Student Research Awards 40 (Fall 2017): 14, https:// digitalcommons.trinity.edu/cgi/viewcontent.cgi ?article=1040\&context=infol it_usra 
regime a year earlier. ${ }^{19}$ The brief but bloody border war upended bilateral Sino-Vietnamese ties and has, along with the South China Sea dispute, ever since played a crucial role in colouring anti-China sentiments in contemporary Vietnam.

National history dictated to Vietnamese students at all levels has featured battles of historical figures who fought against periods of Chinese rule. Those lessons, in one way or another, serve "the purpose of justifying communist rule and the leading role of the [Communist Party of Vietnam]". ${ }^{20}$ The end goals of the state actors in exploiting and harnessing anti-China sentiments in contemporary Vietnam have barely changed: (i) to boost the legitimacy of the regime; ${ }^{21}$ (ii) to shore up national unity; and (iii) to stoke and maintain nationalism. ${ }^{22}$ The authorities have had to walk an increasingly blurry line between doing so and averting stoking extreme Sinophobia for fear that the latter could spiral out of control or turn against the regime. That challenge becomes all the more daunting now that the Internet has enabled anti-China sentiments to morph, evolve and manifest online. The helter-skelter growth of social media has bred a new force of popular non-official actors in the online sphere who are deeply nationalistic but who pursue entirely different political and social agendas. ${ }^{23}$ As both state and popular actors sprint to control public narrative, anti-China sentiments have percolated and been amplified in public discourse.

\footnotetext{
${ }^{19}$ An Dien, "Vietnam, US Inch Closer in Diplomatic Waltz". Thanh Nien News, 23 April 2015, http://www.thanhniennews.com/politics/vietnam-us-inch-closerin-diplomatic-waltz-42539.html

${ }^{20}$ M. Salomon and D.K. Vu, Doi Moi, Education and Identity Formation in Contemporary Vietnam, in: Compare: A Journal of Comparative and International Education 37, no. 3 (2007): 345-63.

${ }^{21}$ Dien Nguyen An Luong, "How Hanoi Is Leveraging Anti-China Sentiments Online”, ISEAS Perspective, no. 2020/115, 13 October 2020, p. 2.

22 Nhi Hoang Thuc Nguyen, "Anti-Chinese Sentiment in Contemporary Vietnam", p. 31.

23 Ibid.
} 


\section{EMERGENCE OF "NEW NATIONALISM" AND THE FACEBOOK FACTOR}

According to $\mathrm{Vu},{ }^{24}$ since the $1980 \mathrm{~s}$, the term "new nationalism" has been used to describe popular or grassroots nationalist movements that challenge the legitimacy of the Communist Party and call for what is perceived to be democracy for Vietnam. Those "new nationalists" could be anyone-intellectuals, retired government officials, professors, youth and students, writers or independent activists. They took great strides in mustering the power of social media-first the blogosphere and then Facebook-to rail against government's thinking and policy. ${ }^{25}$ Their end goals are not to wage a physical war or stir up tension with China, as Nguyen observes. ${ }^{26}$ Instead, they seek to expose inefficiency, weakness and malfeasance in Vietnam's leadership. In a country where being cast as meek and kowtowing to Beijing can be politically damaging, those popular actors have looked to make the most of this dynamic to castigate Vietnam's dealing with China on various fronts, using the very tactic deployed by the authorities-stoking anti-China and nationalist sentiments. Vietnam's wooden propaganda approach and censorship have also thwarted the mainstream media's efforts to fully explain the otherwise perplexing nature of Sino-Vietnamese ties to an already baffled public, lending credence to the narrative peddled by the "new nationalists."

This is the context in which online Vietnamese nationalists entered the fray, coalescing themselves around a "master narrative" consisting of three key messages:

\footnotetext{
${ }^{24}$ Tuong Vu, "The Party v. the People: Anti-China Nationalism in Contemporary Vietnam", Journal of Vietnamese Studies 9, no. 4 (2014): 33-66.

${ }^{25}$ Thiem Hai Bui, "The Influence of Social Media in Vietnam's Elite Politics", Journal of Current Southeast Asian Affairs 35, no. 2 (2016): 93, https://nbnresolving.org/urn/resolver.pl?urn:nbn:de:gbv:18-4-9554

${ }^{26}$ Nhi Hoang Thuc Nguyen, "Anti-Chinese Sentiment in Contemporary Vietnam", p. 34.
} 
- China has never abandoned its expansionist ambitions of drawing Vietnam into its orbit.

- Vietnamese leaders, who have become overly subservient to their Chinese counterparts, are shattering public trust in their ability to defend the country.

- Drastic reforms to the political system-regime change not excluded—are desperately needed to deal with Chinese threats.

The blogosphere was instrumental to the mobilization of the first antiChina protests in Hanoi and Ho Chi Minh City in late 2007 and early 2008 in the wake of China's assertive behaviour in the South China Sea. ${ }^{27}$ Influential bloggers ${ }^{28}$ initiated the call to action on their platforms, detailing logistical information on when, where and how they would take place. Those blogs also articulated the key tenet of the protests—condemn China's aggressive and expansionist activities in the South China Sea and the meek response from the Vietnamese government. The protests took place on a small scale, drawing the participation of chiefly nationalistic Vietnamese bloggers and youths. ${ }^{29}$ Those demonstrations were quickly suppressed, with the authorities arresting several high-profile bloggers for their perceived instigating roles. Even then, the fact that the blogosphere - a relatively less sophisticated social media platform-was able to mobilize protests in the face of state-sponsored censorship and crackdown was a testament to how Vietnamese nationalists had found a new venue to galvanize actions.

After Facebook rolled out its Vietnamese service in 2008, it has taken over as a platform of choice for Internet users, just as the influence of

\footnotetext{
${ }^{27}$ Tuong Vu, "The Party v. the People", p. 43.

28 "Vietnam Jails Three Bloggers in Crackdown on Dissent", Reuters, 24 September 2012, https://www.reuters.com/article/us-vietnam-bloggers/ vietnam-jails-three-bloggers-in-crackdown-on-dissent-idUSBRE88N0CA 20120924

29 "Nũ̃ văn sĩ bị bắt vì Trường Sa" [Female writer arrested because of Spratly protest]. BBC News Vietnamese, 24 December 2007, https://www.bbc.com/ vietnamese/vietnam/story/2007/12/071224_writerarrest
} 
the blogosphere started withering. Various statistics have confirmed that Facebook, Google's YouTube and Zalo have been the most popular social media platforms in Vietnam. ${ }^{30}$ (Zalo is Vietnam's premier chatting app, launched in 2012 and current boasting around 52 million users. ${ }^{31}$ ) Twitter usage has paled in comparison with those platforms while WhatsApp, Signal or Telegram have remained pretty much new to Vietnamese users. The first major illustration of how Facebook was instrumental to unleashing online Vietnamese nationalism materialized in a 2009 incident that revolved around the public backlash against a joint venture under which the Vietnamese government had awarded a Chinese firm the right to mine bauxite - the basic ingredient in the production of aluminium - in the Central Highlands, a strategically important and sensitive region in Vietnam. Even though the case did not lead to the government backtracking on its policy altogether, it was emblematic of how anti-China sentiments fuelled what was perceived to be one of "the most significant domestic confrontations" 32 between the "new nationalists" and the powers-that-be. In fact, in 2008, a handful of Vietnamese environmentalists, scientists and activists had aired their grievances against government-approved plans to develop bauxite mining without an environmental impact study. ${ }^{33}$ But those voices were mostly drowned out until Vo Nguyen Giap, a legendary general who played an

\footnotetext{
${ }^{30}$ Leading active social media platforms among Internet users in Vietnam as of 4th quarter of 2020. Statista, March 2021, https://www.statista.com/ statistics/941843/vietnam-leading-social-media-platforms/

${ }^{31}$ Betty Chum, "Move over, WhatsApp: Zalo is Vietnam's Favorite Messaging App", Tech in Asia, 27 September 2020, https://www.techinasia.com/movewhatapp-zalo-vietnams-favorite-messaging-app

32 Jason Morris-Jung, "The Vietnamese Bauxite Controversy: Towards a More Oppositional Politics”, Journal of Vietnamese Studies 10, no. 1 (2015): 63-109, https://doi.org/10.1525/vs.2015.10.1.63

33 "Opposition still strong to government plans to develop bauxite mines", AsiaNews, 11 April 2010, http://www.asianews.it/news-en/Opposition-stillstrong-to-government-plans-to-develop-bauxite-mines-19904.html
} 
instrumental role in ousting French and American troops from Vietnam, ${ }^{34}$ stepped up to the plate a year later. In his three open letters directed at Vietnam's leadership, Giap not only reiterated the environmental consequences the bauxite-mining projects could bring about but also raised the alarm about the risk of displacing ethnic minority populations. But above all else, Giap's letters warned that the projects would threaten national security by allowing an influx of Chinese workers into the Central Highlands and handing the economic leverage to China. ${ }^{35}$ The "Chinese-threat" trope in the letters opened the floodgates for criticism to be hurled at the government's foreign policy, thrusting the bauxite mining plans into the national spotlight and triggering heated debates at the National Assembly, the nation's legislative body.

Giap's letters were circulated widely on Facebook and the mainstream media, galvanizing the "new nationalists"-retired officials, intellectuals, activists, writers, or journalists-into lodging one petition after the next, calling on Vietnam's leaders to allow for increased public scrutiny of bauxite mining projects. For instance, around 700 individuals set up a Facebook page to register their opposition. ${ }^{36}$ The anti-bauxite movement was expanded to the broader theme of economic overreliance on China. It even gained traction among religious leaders, overseas Vietnamese, political dissidents, or grassroots individuals. In response to Giap's letters and growing public disenchantment, the government gave reassurance that the country would not consider exploiting the mineral at "any cost". Although Vietnamese authorities eventually pressed ahead with the projects, they made some compromises in an apparent gesture

\footnotetext{
${ }^{34}$ Joseph R. Gregory, “Gen. Vo Nguyen Giap, Who Ousted U.S. From Vietnam, Is Dead", New York Times, 4 October 2013, https:/www.nytimes.com/2013/10/05/ world/asia/gen-vo-nguyen-giap-dies.html

${ }^{35}$ John Ruwitch, "Vietnamese War Hero Urges Re-Think of Bauxite Plans", Reuters, 7 May 2009, https://www.reuters.com/article/idUSHAN466228

36 "Bauxite Bashers", The Economist, 25 April 2009, https://www.economist. com/asia/2009/04/23/bauxite-bashers
} 
to soothe an increasingly anti-China nationalist audience at home. Chief among them were the modifying of plans by the government to factor in environmental concerns and impact on ethnic minorities. The legislature, ministries and local authorities would be allowed to inspect how the projects were being implemented. ${ }^{37}$ The government also confirmed that the Chinese firm would not have any equity in the project. ${ }^{38}$

But apparently, with its instrumental role in fanning public criticism in cyberspace, Facebook was becoming a thorn in the eyes of Vietnamese authorities. A supposed draft regulation requiring Internet Service Providers to block Facebook was leaked in mid-2009. ${ }^{39}$ Its authenticity remained in question, but access to Facebook, which boasted around 1 million users at that time, was indeed blocked in Vietnam later that year. ${ }^{40}$ Carl Thayer, an Australia-based veteran Vietnam analyst, encapsulated the dynamic back then: 2009 saw the organization of disparate groups "using Facebook as a rallying area for their shared opposition" to the bauxite mining agreement and to Vietnam's handling of China-related matters in general. ${ }^{41}$ The anti-bauxite movement was also evident of how anti-China sentiments proved an enduring feature of Vietnam's popular nationalistic movements. Significantly, as Thayer observes, "for the first time the competency of the government to decide on large-scale development projects was called into question by a broad

37 Carlyle A. Thayer, "Political Legitimacy of Vietnam's One Party-State: Challenges and Responses", Journal of Current Southeast Asian Affairs 28, no. 4 (2009): 47-70.

38 "Vietnam Bauxite Decision May Affect Alcoa Project", Reuters, 29 April 2009, https://www.reuters.com/article/vietnam-bauxite-idUSHAN45994820090429

${ }^{39}$ Helen Clark, "Vietnam's Dysfunctional Relationship with the Web", XIndex, 21 August 2013, https://www.indexoncensorship.org/2013/08/vietnamsdysfunctional-relationship-with-the-web/

${ }^{40}$ Associated Press, "Vietnam Internet Users Fear Facebook Blackout", Sydney Morning Herald, 17 November 2009, https://www.smh.com.au/technology/ vietnam-internet-users-fear-facebook-blackout-20091117-iki0.html

${ }^{41}$ Clark, "Vietnam's Dysfunctional Relationship with the Web". 
national coalition of mainstream elites including environmentalists, scientists, economists, social scientists, and retired officials." ${ }^{42}$

Since 2009, against the backdrop of increasing state-sanctioned crackdown on the blogosphere ${ }^{43}$ and the lack of Vietnamese interest in Twitter, ${ }^{44}$ Facebook has proved an indispensable platform for online Vietnamese nationalists to galvanize actions both online and offline, in some cases resulting in physical mobilization, violence and even deadly riots. Calls for anti-China protests were initiated by high-profile bloggers, who also joined Facebook and sought to leverage their influence on the platform. ${ }^{45}$ Thanks to its connectivity and intimacy, Facebook enabled Vietnamese Internet users to find camaraderie in their shared anti-China sentiments, widely circulate appeals for demonstrations, jointly hammer out workarounds to state control, or share pictures and videos of the protests and crackdown on them to draw increased attention. ${ }^{46}$ Nowhere were those features more manifest than in anti-China demonstrations over the South China Sea dispute that broke out sporadically over the past decade. In 2011, after Chinese patrol boats attacked a Vietnamese oil survey off the coast of Vietnam, anti-Chinese protests took place every Sunday in Hanoi and Ho Chi Minh City for two months. In 2014, China's placement of an oil rig in Vietnam's exclusive economic zone in the South China Sea triggered a widespread backlash, plunging the two

\footnotetext{
${ }^{42}$ Thayer, "Political Legitimacy of Vietnam's One Party-State".

${ }^{43}$ Michael Gray, Control and Dissent in Vietnam's Online World (Canada: The SecDev Foundation, Tia Sang Vietnam Research Report, February 2015), p. 7, https://secdev-foundation.org/wp-content/uploads/2015/02/Vietnam.Control andDissent.Feb15.pdf

${ }^{44}$ Anh-Minh Do, “The Real Reason Why Facebook Dominates Vietnam but Twitter Could Never Make It”, TechinAsia, 8 May 2014. https://www.techinasia. com/vietnam-loves-facebook-not-twitter

45 “Authorities Target Bloggers at Protests", Radio Free Asia, 2 July 2021, https:// www.rfa.org/english/news/vietnam/bloggers-07022012171255.html

${ }^{46}$ Huong Nguyen, "Internet Stirs Activism in Vietnam", YaleGlobal Online, 11 May 2021, https://yaleglobal.yale.edu/content/internet-stirs-activism-vietnam
} 
ideological allies into their worst diplomatic crisis since the 1979 border war. ${ }^{47}$ As part of its multipronged response, Vietnam allowed the public to vent their spleen on social media and the comment sections of staterun news outlets. Such sentiments led Vietnamese patriots to organize anti-China street protests, But the protests later morphed into deadly riots, taking a heavy toll on businesses from South Korea, Singapore, Malaysia and Taiwan. These were mistaken for Chinese firms.

The "master narrative" of those Facebook-mobilized anti-China protests, which was more or less dictated by the "new nationalists", comprised three key messages:

- In the face of China's growing aggressiveness and expansionism, the response of Vietnamese leaders was meek.

- It was time every single Vietnamese patriot had a say and took action to protect the country's sovereignty and independence.

- The urgent need for Vietnam to get out of China's orbit was never more palpable.

While Facebook did prove a crucial tool for information exchange and the coordination of collective action in those anti-China demonstrations, a growing body of evidence has shown that social media alone could not have fuelled protests. The materialization of real-life protests is contingent on a confluence of different pull factors and particular geopolitical contexts. ${ }^{48}$ In Vietnam, anti-China sentiments had already existed, waiting to merge with other important triggers such as geopolitical thinking and

\footnotetext{
${ }^{47}$ Kate Hodal and Jonathan Kaiman, “At Least 21 Dead in Vietnam Anti-China Protests over Oil Rig”, The Guardian, 15 May 2014, https://www.theguardian. com /world/2014/may/15/vietnam-anti-china-protests-oil-rig-dead-injured ${ }^{48}$ Bryan H. Druzin and Jessica Li, "The Power of the Keystroke: Is Social Media the Radical Democratizing Force We've Been Led to Believe it is?", Harvard Human Rights Journal 28, no. 1 (2015): 1, https://harvardhrj.com/2015/02/thepower-of-the-keystroke-is-social-media-the-radical-democratizing-force-wevebeen-led-to-believe-it-is
} 
territorial disputes to unleash anti-China protests. In that context, social media—Facebook included — could at best serve as a helpful conduit. To put things in perspective, in the wake of the dramatic events unfolding in Egypt and Tunisia in 2011, a handful of activists also tried to capitalize on that pretext and used Facebook to call for an Arab Spring-style uprising in Vietnam, ${ }^{49}$ a move that elicited lacklustre public attention. ${ }^{50}$ Also, the role of the authorities could not be discounted in accounting for the mass mobilization and physical violence. Even though Vietnamese authorities eventually suppressed them in 2011 and 2014, ${ }^{51}$ the anti-China protests had got some tacit official approval to go ahead in the first place. ${ }^{52}$ According to Jessica Chen Weiss, nationalist mobilization, if sincere, can serve as a "diplomatic boon". ${ }^{53}$ They enabled authoritarian leaders to cite popular opinion to claim that they have nationalistic sentiments to placate at home, rendering any diplomatic concession politically costly. Weiss sums up the authorities' rationale for both greenlighting and suppressing nationalist demonstrations: "By allowing antiforeign protests, autocrats can signal their resolve to stand firm, demonstrate the extent of public anger, and justify an unyielding bargaining stance." On the other hand, repressing nationalist protests allows autocrats to play "good cop" to the hawkish voices in society and "signal reassurance and their commitment to a more cooperative, flexible diplomatic stance."

49 "Vietnam activist Nguyen Dan Que held for uprising call", BBC News, 28 February 2011, https:/www.bbc.com/news/world-asia-pacific-12595261

50 Yen Duong, "The Political Apathy of Vietnamese Youth", New Naratif, 1 December 2017, https://newnaratif.com/journalism/the-political-apathy-ofvietnamese-youth

${ }^{51}$ Phuong Hoang, "Domestic Protests and Foreign Policy: An Examination of Anti-China Protests in Vietnam and Vietnamese Policy towards the South China Sea”, Journal of Asian Security and International Affairs 6, no. 1 (2019): 1-29.

${ }^{52}$ Nhung T. Bui, "Managing Anti-China Nationalism in Vietnam: Evidence from the Media During the 2014 Oil Rig Crisis", Pacific Review 30, no. 2 (2017): 169-87, https://doi.org/10.1080/09512748.2016.1201132

${ }^{53}$ X. Pu, "Book review: Jessica Chen Weiss, Powerful Patriots: Nationalist Protest in China's Foreign Relations", Journal of Chinese Political Science 21 (2016): 501-2, https://doi.org/10.1007/s11366-016-9440-0 
Vietnamese authorities were likely to have realized the hefty price of stoking the nationalist flames too far. Those lessons left indelible imprints on how the authorities revised their tactics to deal with public sentiment online, in a country where social media can serve as a pressure release valve for public opinion as long as collective action is nipped in the bud.

\section{FEATURES OF ONLINE VIETNAMESE NATIONALISM}

This section examines more recent prominent cases of online Vietnamese nationalism by analysing the contents of posts and comments on 11 Facebook pages which have been most active in mobilizing online nationalism. These are divided into three categories:

- Category I-State-sponsored groups: ATK Thu do gio ngan (ATK The Capital of Vietnam revolution); ${ }^{54}$ toi yeu To quoc Viet Nam XHCN (I love Socialist Vietnam Fatherland); ${ }^{55}$ Cua ngo Thu Do (Capital Gateway); ${ }^{56}$ and Phu Binh mien que an tinh (Phu Binh a hospitable hometown). ${ }^{57}$ These four groups are part of Vietnam's 10,000-strong military cyber unit, dubbed Force 47.

- Category II-Pro-regime groups: Tifosi; ${ }^{58} \mathrm{Hoc}$ vien phong chong phan dong (Anti-reactionary Academy); 59 Thong tin phong chong phan dong (Anti-reactionary Information); ${ }^{60}$ and Bao Lua (Firestorm) ${ }^{61}$ They have amassed a strong base of followers $(184,000,234,000$,

\footnotetext{
${ }^{54}$ https://www.facebook.com/groups/172388613444084

${ }^{55} \mathrm{https}$ ://www.facebook.com/groups/293849994842179

${ }^{56}$ https://www.facebook.com/C\%E1\%BB\%ADa-ng\%C3\%B5-Th\%E1\%BB $\%$ A7-\%C4\%90\%C3\%B4-103629354829772

${ }^{57}$ https://www.facebook.com/groups/383505648911005

${ }^{58}$ https://www.facebook.com/tifosi.hpo

${ }^{59}$ https://www.facebook.com/hocvienphongchongphandong

${ }^{60}$ https://www.facebook.com/thongtinchongphandong/

${ }^{61}$ https://www.facebook.com/8.baolua
} 
141,000 and 68,000 respectively).

- Category III-Neutral/Private groups: Bi mat Showbiz (Showbiz Secrets); $;{ }^{62}$ Hoi Khau Nghiep (Karma Group); ${ }^{63}$ and Maybe You Missed This $\mathrm{F}^{* * *}$ king News. ${ }^{64}$ These groups have also built up a strong base of followers $(1,575,000,385,000$ and 794,000 respectively).

An analysis of the activity on these pages suggests the following characteristics:

- Based on the dates of their first posts, all state-sponsored Facebook groups were not active until mid-2018. Pro-regime groups had been active a bit earlier, but their posts did not elicit considerable engagements until mid-2017 (Table 1).

- The dismal number of followers of state-sponsored groups seems to stem from the fact that they are under the control of a local government-Thai Nguyen Province. Force 47 has been in existence since late 2017, ${ }^{65}$ but it was not until March 2021 that Thai Nguyen authorities acknowledged publicly that the four groups were part of the military cyber unit. ${ }^{66}$ It remains unclear when state-sponsored groups with larger bases of followers will be revealed.

- Neutral/private groups are teeming with jokes, memes and discussions

\footnotetext{
62 https://www.facebook.com/bmsb.vnn/

63 https://www.facebook.com/groups/390756862059577/permalink/ 430396868095576/

64 https://www.facebook.com/groups/maybefnews/permalink/ 1468068193551419

65 James Hookway, “Introducing Force 47, Vietnam's New Weapon Against Online Dissent”, Wall Street Journal, 31 December 2017, https://www.wsj. com/articles/introducing-force-47-vietnams-new-weapon-against-onlinedissent-1514721606

${ }^{66}$ Hang Nga, "Phát huy vai trò lực lượng 47 trong đấu tranh trên không gian mạng" [Utilize the role of Force 47 in the cyberspace battlefield], Thai Nguyen Newspaper, 29 March 2021, http://baothainguyen.vn/trang-in-282516.html ?fbclid=IwAR3IXeNAYvxJM0EjvAgH8rKCY1W8v5ax7JolTdCmENRbkip8G372Ef0vOI
} 


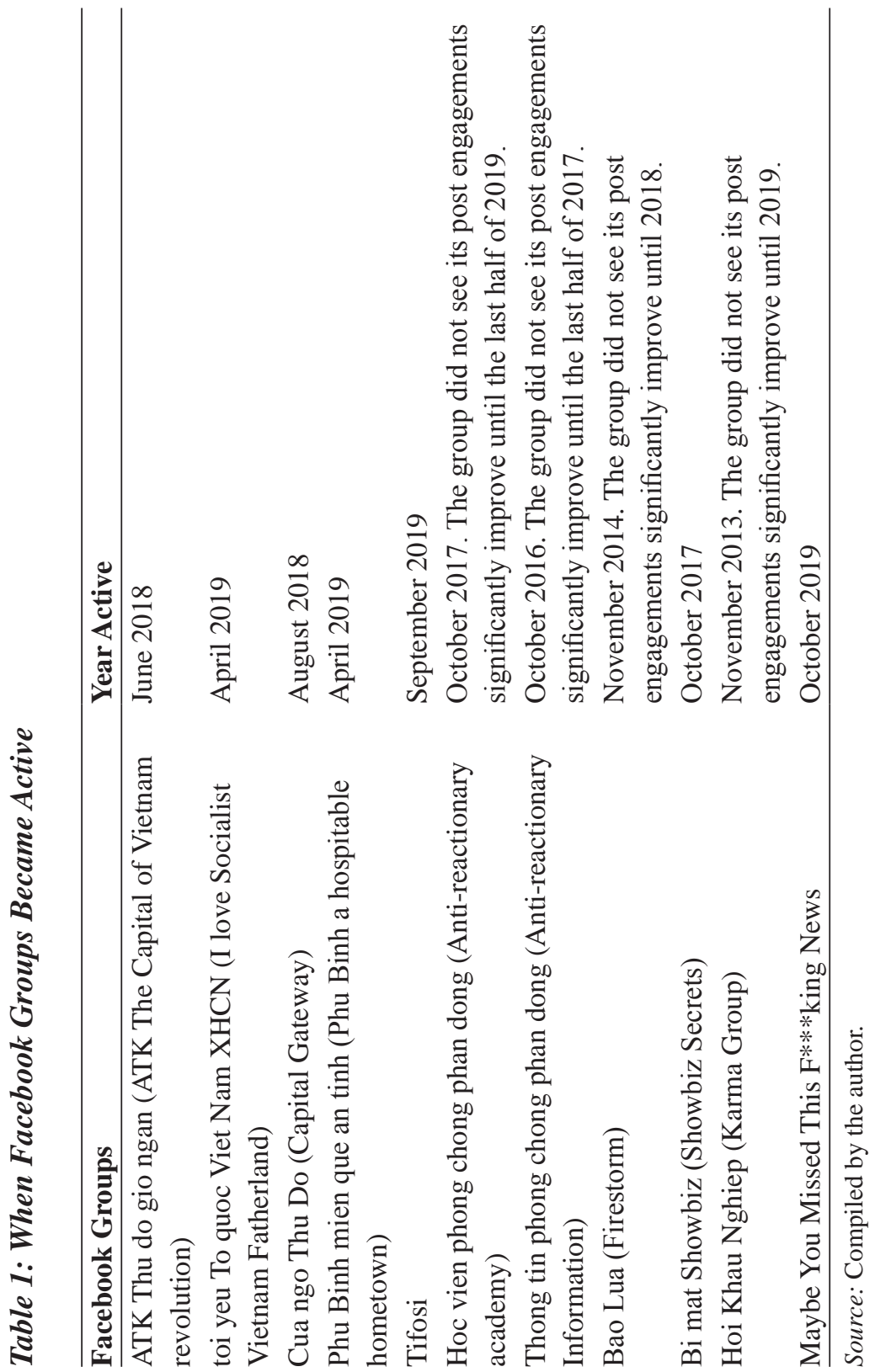


on all garden-variety and sensational topics excepting politics. They have also amassed the largest followings among the three categories. These neutral/private groups have also participated in promoting the nationalist narratives when issues resonate strongly amongst the general netizen population.

- While the government has stopped short of officially recognizing pro-regime pages, the latter have either implicitly or publicly adopted a pro-government stance and tend to be the first among the three categories analysed to propagate nationalistic narratives. Pro-regime groups were also the only category that produced original nationalist narratives, which were later picked up and spread by the rest in the other two categories.

Three high-profile cases of online nationalism have been examined. The first involves the social media-fuelled boycott call against H\&M, the Swedish fashion retailer. The second case relates to the online backlash against comments made by Singapore Prime Minister Lee Hsien Loong about Vietnam's role in ousting the genocidal Khmer Rouge regime. The last looks into the public outcry over a wealthy Vietnamese COVID-19 patient.

Based on the analysis of these case studies, several broad features of Vietnamese online nationalism are distilled:

- Online Vietnamese nationalism has mostly revolved around and been triggered by anti-China sentiments. There is no black-and-white answer to the question of whether the nationalist expression was organic or state-instigated. What is more certain is that in a country where anti-China sentiments have permeated public discourse, ${ }^{67}$ these serve as a ready tinderbox that can be easily ignited. Against that backdrop, Vietnamese authorities have sometimes just played a facilitating role in stoking nationalist sentiments and exploiting them.

- Apart from anti-China sentiments, dislike of the West's claims of

${ }^{67}$ Gary Sands, "In Vietnam, Protests Highlight Anti-Chinese Sentiment". The Diplomat, 12 June 2018, https://thediplomat.com/2018/06/in-vietnam-protestshighlight-anti-chinese-sentiment/ 
moral superiority has also emerged as a salient trigger for online Vietnamese nationalism. But unlike the narratives associated with antiChina sentiments, anti-West narratives tend to be more pro-regime in nature. In the case study examined, the Vietnamese government had been able to gain exceptional public approval for pushing back the coronavirus. Basking in a sense of pride in Vietnam's achievements, Internet users had bristled at what they perceived as unfair, biased or even racist narrative against their country perpetuated by the West. Intriguingly, many of those online nationalists opted to defend Vietnam and the regime even though they were critical of domestic political affairs.

- Unlike Facebook-fuelled anti-China demonstrations over South China Sea issues, which last took place in 2018, the online nationalist campaigns examined in this paper seem short-lived and their impact fleeting and limited to online rhetoric. This suggests that while the issues may touch on latent popular sensitivities, they may not have been compelling enough to sustain prolonged online activism and mobilization. It is also possible that in the two cases where anti-China sentiments were triggered, the Vietnamese authorities stepped in on the side of the online nationalists and were seen, in some measure, to have addressed their grievances.

\section{The H\&M Saga}

A confluence of anti-China sentiments, geopolitical thinking and territorial disputes was the trigger for the nationalist expression in this case. In early April 2021, H\&M was facing a growing uproar and boycott call from social media users in Vietnam who accused it of capitulating to Beijing to use a map that contains the controversial nine-dash line. The nine-dash line includes large swathes of the South China Sea and is vehemently opposed by Hanoi. ${ }^{68}$ Despite the lack of compelling evidence to substantiate such allegations against H\&M, in Vietnam it was quickly

\footnotetext{
${ }^{68}$ Kristin Huang, "H\&M Upsets Vietnam After Kowtowing to Beijing over 'Problematic Map'”, South China Morning Post, 3 April 2021, https://www. scmp.com/news/china/diplomacy/article/3128218/hm-upsets-vietnam-afterkowtowing-beijing-over-problematic-map
} 
framed as a sign that the Swedish apparel maker had acquiesced to China's territorial claims. Pro-regime Facebook groups took the lead in amplifying the accusations and calling for a boycott against H\&M. This narrative ricocheted throughout social media, sending the hashtag \#ApologizeToVietNam viral. After social media posts lit the flames, ordinary Internet users-including many of my Facebook friends - were thrown for a loop and joined in.

Interestingly, state-sponsored Facebook pages did not circulate many posts about this case while the other groups analysed for this section were very active in trending the nationalist sentiment. As the pattern shows: Pro-regime groups were the first to deliver the blistering indictment of H\&M online. In this case, although the average posts were almost equal between pro-regime and neutral/private groups, the latter eclipsed the former where the number of average reactions, shares and comments (Figure 1) were concerned.

Figure 1: Average Facebook Posts and Their Engagements on Three Categories in the H\&M Saga

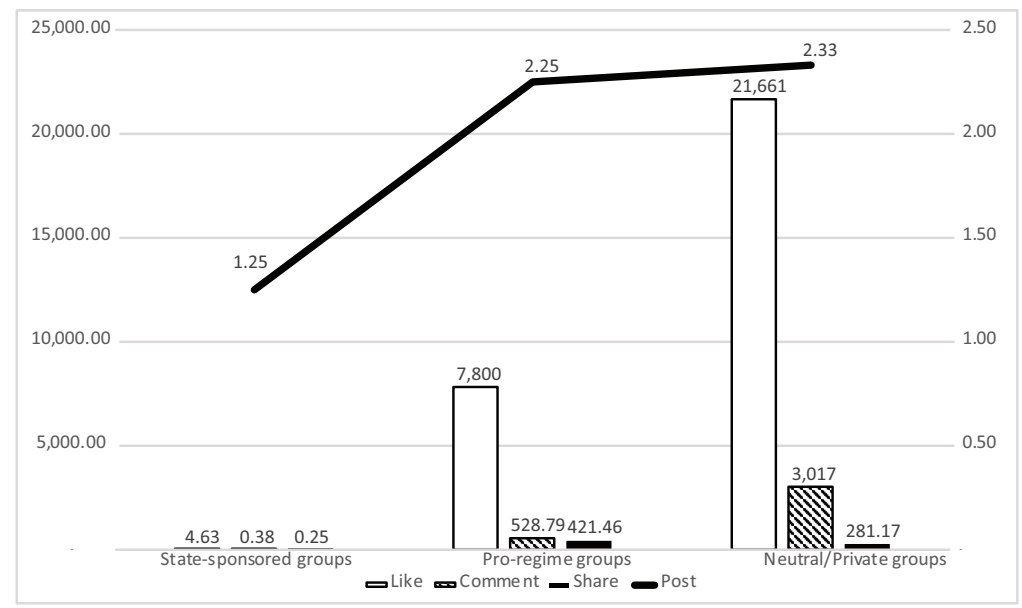

Source: Compiled by the author. 
The main thrust of posts on pro-regime groups ${ }^{69}$ more or less dovetailed with the "master narrative" that ensued and reverberated through both social media and the mainstream media:

- To regain the trust of Chinese customers, H\&M had opted to kowtow to China by using a map that contained the nine-dash line.

- Such actions violated Vietnamese laws and undermined its maritime sovereignty, insulting the country and its people. H\&M was doing so even though it was making profits in Vietnam.

- H\&M must make a correction to its faulty map. Otherwise, its actions would merit a boycott in Vietnam.

An analysis of most-used keywords in all posts and comments on Facebook groups analysed for this section shows three dominant themes: anti-China sentiments, Vietnam's maritime sovereignty and the boycott call. (Figure 2)

\section{Figure 2: Keywords on Social Media Discussion on the H\&M Saga}

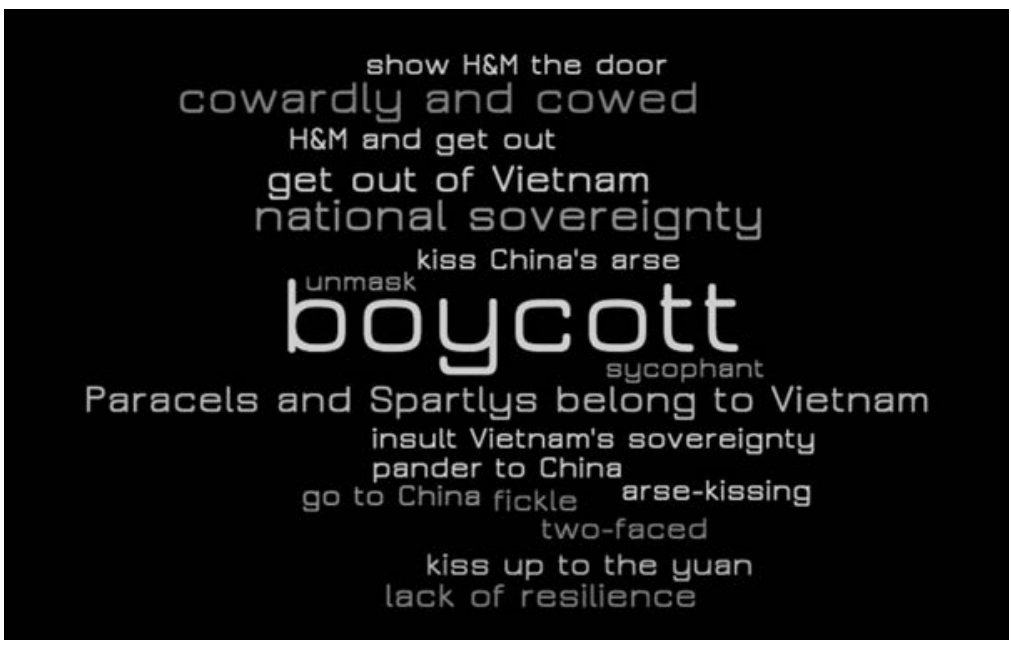

Source: Compiled by the author.

${ }^{69} \mathrm{https}: / /$ www.facebook.com/tifosi.hpo/posts/544401433622521 
But as it turned out, Vietnamese Internet users appeared not to have followed through with the boycott call against H\&M. This research programme at ISEAS has generated relevant keywords on the topic of anti-China sentiments (see Appendix) and analysed the discussion on them in Vietnam's online sphere since late July 2020. More relevant keywords were added to the topic to reflect how the H\&M saga vaulted anti-China sentiments online to an unprecedented peak: The number of social media posts with anti-Chinese sentiments hit 4,558 on 3 April 2021 - the very day after the narrative of the H\&M saga first circulated in Vietnam (Figure 3). But the peak did not last long, quickly petering out and being in decline since. A major chunk of the content (nearly 80 per cent) originated from social media, chiefly Facebook (Figure 4).

In this case, it was not long before many of Vietnam's state-run news outlets swung into action to propagate the same narrative that had appeared in the cybersphere. In a country without free media, if Vietnamese censors had wanted to gut media coverage on the H\&M saga, they would have barged in. A 2020 study by the Washingtonbased Center for Naval Analysis also confirmed a pattern in which Vietnamese authorities sometimes calibrated media coverage to exhibit

Figure 3: Online Posts on Anti-China Sentiments since July 2020

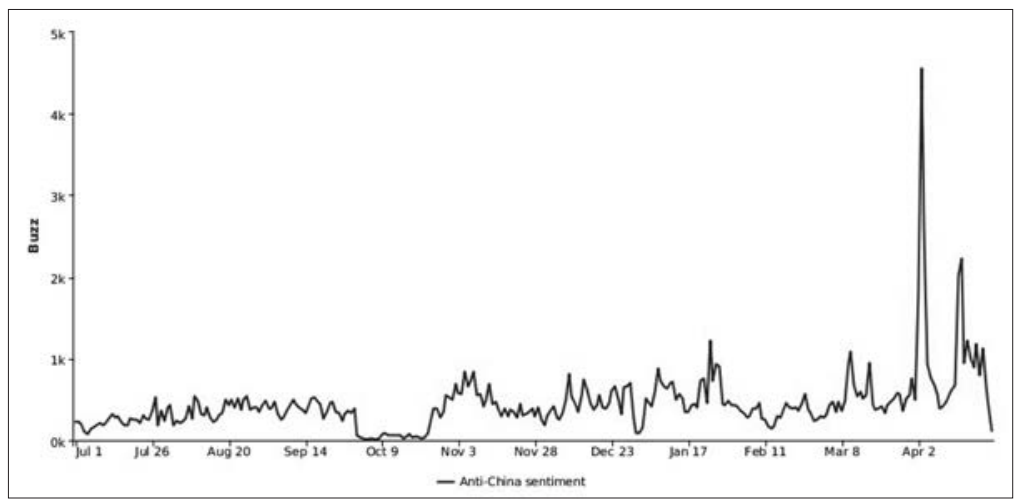

Source: ISEAS - Yusof Ishak Institute and Isentia. 


\section{Figure 4: Online Posts on Anti-China Sentiments in Different Channels}

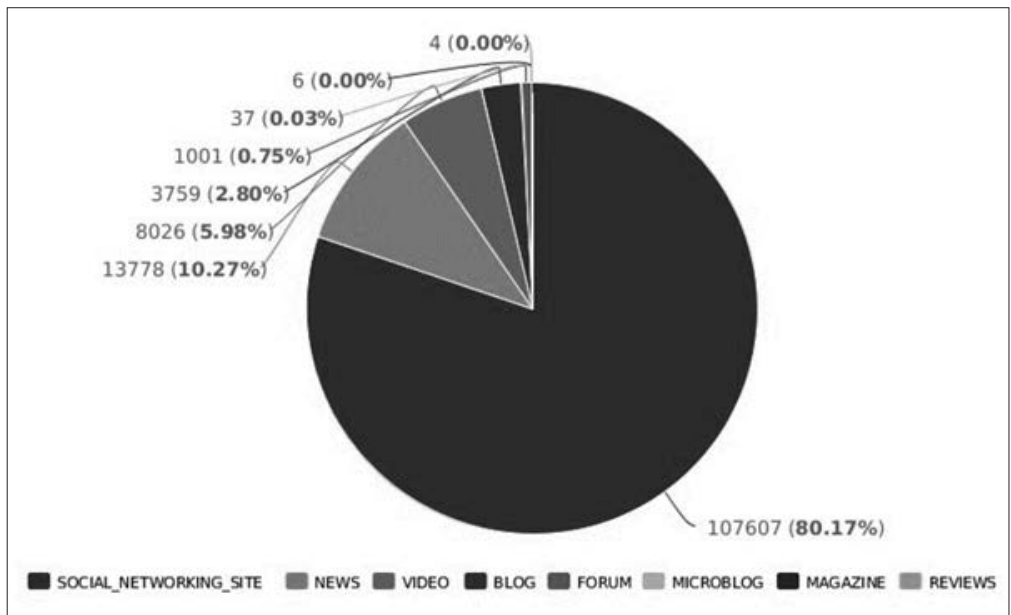

Source: ISEAS - Yusof Ishak Institute and Isentia.

a harder stance on China with regards to maritime territorial disputes. ${ }^{70}$ As nationalist sentiments raged, Vietnam's Ministry of Foreign Affairs used the controversy to issue a statement that dismissed China's ninedash line claim.

It took one week, 2 to 8 April, for the H\&M saga to die down. But still, it proved a testament to how increasingly adroit Vietnam authorities have become at leveraging the confluence of nationalist sentiment and social media. In doing so, the authorities were also able to telegraph significant messages: First, Vietnam too has strong nationalistic sentiments that should not be trifled with. Second, few moves risk stirring up a hornet's

${ }^{70}$ Ryan Loomis and Heidi Holz, “China’s Efforts to Shape the Information Environment in Vietnam", Center for Naval Analysis (2020), p. 48, https://www. cna.org/CNA_files/PDF/IIM-2020-U-026222-Final.pdf?fbclid= IwAR22TwwmL_eWZzc5PZEzz1DhcgrI9GdCVPglatX5Elb_OpYWUdgjric_ ha $\mathrm{E}$ 
nest in Vietnam more than one that purportedly validates the nine-dash claim. Finally, even though Hanoi's economic muscle is dwarfed by China's, in some cases, winning over — or at least not offending —online patriots should become a crucial consideration for companies seeking to enter the Vietnamese market. More importantly, the case also showed how the agendas of state and popular players could converge and amplify online. But that was not the first time for such a dynamic to manifest, as we will shall see in the next case, which involved Singapore's prime minister.

\section{The Online Backlash against Prime Minister Lee Hsien Loong's Comments}

Anti-China sentiments again triggered nationalist expression in this case. There were also other factors that reflected different dimensions of online Vietnamese nationalism: national pride and superiority as well as hawkishness on foreign policy and geopolitical diplomacy. ${ }^{71}$ In June 2019, Singapore Prime Minister Lee Hsien Loong's tribute to the late Thai premier General Prem Tinsulanonda contained the words "invasion" and "occupation" to refer to Vietnam's actions to oust the Khmer Rouge in the late 1970s, language that Vietnam and Cambodia said was tantamount to support for the genocidal regime of Pol Pot. ${ }^{72}$ This sparked an online backlash and a diplomatic crisis not seen in years between Singapore and its two Southeast Asian neighbours. Vietnam's online community also took the lead in flagging the issue. Angry mobs of netizens stormed the Facebook page of Prime Minister Lee, demanding an apology and a correction of what they perceived as a distorted historical

\footnotetext{
${ }^{71}$ Z.K. Wei, “China's Little Pinks? Nationalism Among Elite University Students in Hangzhou”, Asian Survey 59, no. 5 (2019): 822-43.

72 Dewey Sim and Lynn Lee, “Hun Sen accuses Singapore PM Lee Hsien Loong of ‘Supporting Genocide’ as War of Words over Cambodia’s Khmer Rouge-Era Escalates", South China Morning Post, 6 June 2019, https://www.scmp.com/ week-asia/politics/article/3013336/did-vietnam-invade-cambodia-or-save-itsingapore-pm-lee-hsien
} 
reflection. In this case, Vietnamese authorities did not remain reticent for long. Besides lodging a diplomatic protest against Singapore, they quickly joined their Cambodian counterparts in the chorus of criticism against Prime Minister Lee’s comments, saying "they did not objectively reflect the historical truth".

Pro-regime groups analysed for this section and other Facebook pages purportedly, run by cyber troops or public opinion shapers, were the most active in trending those sentiments (see Figure 5). Another potential popular actor, which was not part of the state-sanctioned cyber unit but which should not be discounted altogether, were zealous online nationalists. As significant crossovers occur among these groups, ${ }^{73}$

\section{Figure 5: Average Facebook Posts and Their Engagements in} Three Categories in the Case of PM Lee Hsien Loong

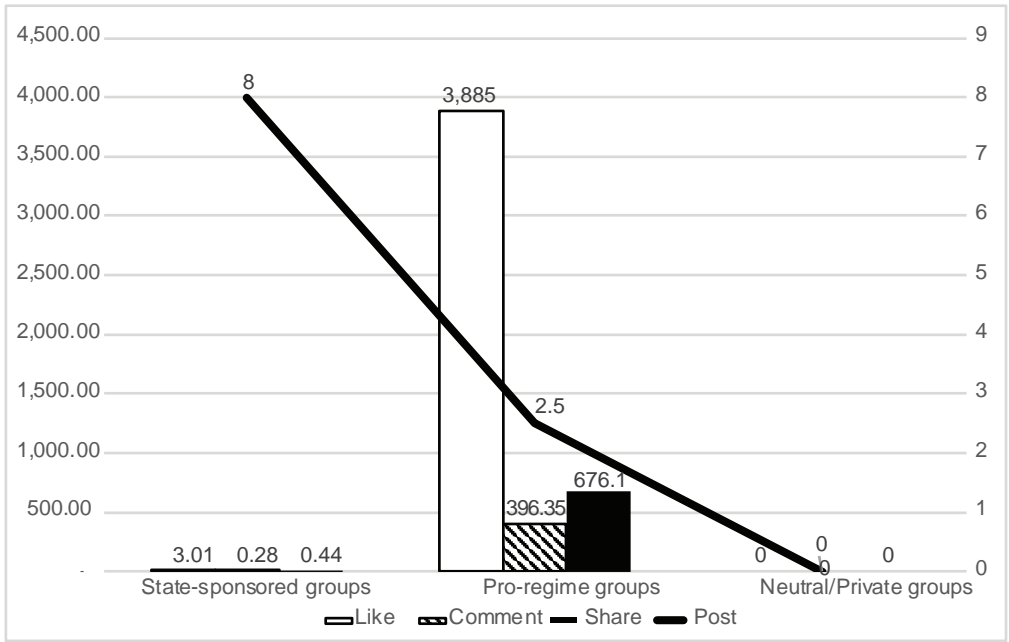

Source: Compiled by the author.

${ }^{73}$ Dien Nguyen An Luong, "How The Vietnamese State Uses Cyber Troops to Shape Online Discourse". 
it is hard to ascertain who played a more decisive role in shaping the nationalist narrative and spreading it. But in this case, one difference was that all three Facebook pages under the category of Neutral/Private groups did not participate. One possible explanation: Unlike the H\&M saga that also involved popular consumer behaviour, this case was purely about politics and could have proved of little interest to young social media users who account for a big chunk of followers of those groups. According to the 2020 Next Generation survey conducted by the British Council, three in four (78 per cent) Vietnamese youths polled said they had "no engagement" with the country's politics. ${ }^{74}$ In this case, the average Facebook posts in the state-sponsored category outnumbered those on pro-regime groups. But intriguingly, the post engagements in pro-regime groups exceeded those in the state-sponsored category by a wide margin.

The strong backlash, both online and in real life, from Vietnam could have caught Singaporean authorities off-guard in the first place. But a closer look at history and the geopolitical context helps shed light on such a reaction. The "master narrative" circulated by online nationalists in this case was again pretty much aligned with Vietnam's official line:

- While the rest of the world turned their backs on the atrocities committed by the Khmer Rouge in Cambodia, Vietnam dispatched soldiers to rescue its neighbour and oust a brutal regime that was backed by Beijing. ${ }^{75}$

- By just responding to ample provocation from the Khmer Rouge, Vietnam's actions in Cambodia were totally justified. Vietnam should therefore have been credited with "liberating" Cambodia instead of being accused of "invading" the country.

\footnotetext{
74 "Next Generation Vietnam". British Council, August 2020, https://www. britishcouncil.org/sites/default/files/1045_next_generation_vietnam_final_web. pdf

${ }^{75}$ Kevin Doyle, "Vietnam's Forgotten Cambodian War", BBC News, 14 September 2019, https://www.bbc.com/news/world-asia-29106034
} 
- In making those comments, Prime Minister Lee Hsien Loong distorted history, disregarded sacrifices made by Vietnamese soldiers and hurt the feelings of the people.

State and popular actors also diverged in their approaches: While Vietnamese leaders did not publicly call for an apology from Prime Minister Lee Hsien Loong, online nationalists vociferously pushed for it. In fact, the "Lee-Hsien-Loong-owes-Vietnam-an-apology" meme became one of the most popular online. Anti-reactionary Academy, a pro-regime group analysed for this section, went even further by pointing the finger at what it perceived as Singapore's ulterior motive in this regard. In a post dated 7 June $2019,{ }^{76}$ the group floated the possibility that Prime Minister Lee made the comments in the context of the USChina trade war continuing to affect Singapore's economy. ${ }^{77}$ According to the post, in dismissing Vietnam's "righteous" actions in Cambodia, the Singaporean prime minster was seeking to curry favour with both China and the US, which had also supported and bankrolled the Khmer Rouge. ${ }^{78}$ Anti-Singapore sentiments were somewhat conflated with antiChina sentiments.

Such sentiments were captured in an analysis of most-used keywords in a total of ten posts and all comments on the four pro-regime Vietnamese Facebook groups as well as public responses on the Facebook page of Prime Minister Lee Hsien Loong (Figure 6).

76 https://www.facebook.com/hocvienphongchongphandong/posts/
1115272068662547

77 Finbarr Bermingham, "Singapore's Economic Downturn Continues as US-China Trade War Wreaks Havoc on Asia Export Hubs", South China Morning Post, 17 July 2019, https://www.scmp.com/economy/china-economy/ article/3018935/singapores-economic-downturn-continues-us-china-trade-war

${ }^{78}$ Casey Quackenbush, “40 Years After the Fall of the Khmer Rouge, Cambodia Still Grapples With Pol Pot's Brutal Legacy”. TIME, 7 January 2019, https:// time.com/5486460/pol-pot-cambodia-1979/ 


\section{Figure 6: Keywords on Social Media Discussions on PM Lee's Comments}

\section{owe Vietnam an apology}

\section{pander to China} stupid old man

\section{ungrateful animal Chinese unintelligent prime minister}

Source: Compiled by the author.

But the diplomatic run-in has apparently not had a major bearing on the overall ties between Vietnam and Singapore since. The island nation remained the third-largest investor in Vietnam in 201979 and became the largest last year. ${ }^{80}$ That appeared to be also the case in the online sphere. One year after Prime Minister Lee made his comments, Tifosi, the pro-regime Facebook group, circulated a post as a reminder that Singapore was "one of the most ardent supporters of the Khmer Rouge regime". ${ }^{11}$ But other than that, the other Facebook groups analysed for

\footnotetext{
79 "Singapore Tops List of Foreign Investors in Vietnam", Vietnam Economic News, 18 November 2020, http://ven.vn/singapore-tops-list-of-foreign-investorsin-vietnam-43987.html\#: :text=Singapore \%20is\%20currently $\% 20$ the $\% 20$ third,US\%247.3\%20billion\%20in\%202019.

${ }^{80}$ Malie Nguyen, "Singapore is Vietnam's Leading Foreign Investor in 2020", Vietnam Times, 31 December 2020, https://vietnamtimes.org.vn/singapore-isvietnams-leading-foreign-investor-in-2020-26950.html

${ }^{81}$ https://www.facebook.com/tifosi.hpo/posts/344883086907691
} 
this section, as well as many other pro-government Facebook groups, have stopped broaching the issue since it was settled through official diplomatic channels. By and large, it took roughly three weeks for the online backlash to almost totally subside.

As analysed, expressions of online nationalism in the cases of the boycott call against H\&M and PM Lee Hsien Loong's comments revolved around anti-China triggers that had already existed or been pent-up. But as we shall see in the next case study, the COVID-19 pandemic has opened a new venue for online nationalism and seen Vietnamese authorities form an unlikely alliance with patriots who are not necessarily supportive of the regime.

\section{The "Ungrateful” COVID-19 Patient}

This case was an instance in which online nationalistic mobilization coalesced around a pro-regime narrative that was driven by extraordinarily high public approval of the Vietnamese government's handling of the COVID-19 crisis. In September 2020, after a New Yorker feature, headlined "The Public Shaming Pandemic", 82 came out, an online backlash ensued that saw livid Vietnamese netizens flocking to the Facebook page of the prestigious magazine to lash out at one of the most high-profile Vietnamese COVID-19 patients. Two Vietnamese daughters of a wealthy tycoon were featured in the piece, among other patients who incurred public wrath for their roles in spreading the coronavirus. One of them, Nhung Nguyen, returned to Hanoi from London in early March 2020, and was tested positive for COVID-19 several days later. Dubbed Patient 17, she apparently hushed up her travel to Italy to avoid quarantine, ${ }^{83}$ a move that set the stage for another wave of massive

${ }^{82}$ D.T. Max, "The Public-Shaming Pandemic". New Yorker, 21 September 2020, https://www.newyorker.com/magazine/2020/09/28/the-public-shamingpandemic

${ }^{83} \mathrm{Vu}$ Lam, "Public Shaming Is Terrible, but so Is Poor Journalism", The Diplomat, 19 October 2020, https://thediplomat.com/2020/10/public-shamingis-terrible-but-so-is-poor-journalism/ 
infections in a country that had gone virus-free for twenty-two days. As a result, Patient 17 and her sister in Europe triggered a popular backlash, which was all the more potent in the online sphere.

Besides panning the New Yorker for what many perceived as a narrative about Vietnam that was riddled with several major factual errors and bias, ${ }^{84}$ Internet users vented their main grievances against Patient 17, calling her "ungrateful", "contemptible", or "elitist" and even demanding her deportation. The reasons? Chief among them was the fact that after being treated successfully by Vietnamese doctors to whom her family said they were grateful, Patient 17 later used a Western news outlet to blame the public shaming against her and her sister on their social and wealth status. "In Vietnam, we are too privileged —we travel too much... If this was Paris Hilton, there would not be so much fuss," Patient 17 told the New Yorker in September 2020, referring to the rationale for the public backlash she and her sister had been faced with six months earlier. For the angry mobs, it was this attitude which they saw as unpatriotic, anti-social and entitled that was the real trigger for the online uproar.

All three categories analysed for this section participated in circulating the nationalist narrative with pro-regime groups being the most active. Again, state-sponsored groups attracted little engagement even though their average posts were no fewer than those in the other two categories. Neutral/private groups recorded the highest post engagements, probably thanks to their large followings (Figure 7).

Notably, this case also saw online nationalists, many of whom may not have necessarily defended the regime under other circumstances, and the mainstream media being almost on the same page in organizing the "master narrative" that comprised three key messages:

- Patient 17 bit the hand that feeds her.

- For Vietnamese, a majority of whom have been highly compliant with drastic measures enacted by the government to contain the pandemic, giving up a modicum of privacy if it means saving lives was no big deal.

${ }^{84}$ Ibid. 
Figure 7: Average Facebook Posts and Their Engagements on Three Categories in the Case of Patient 17

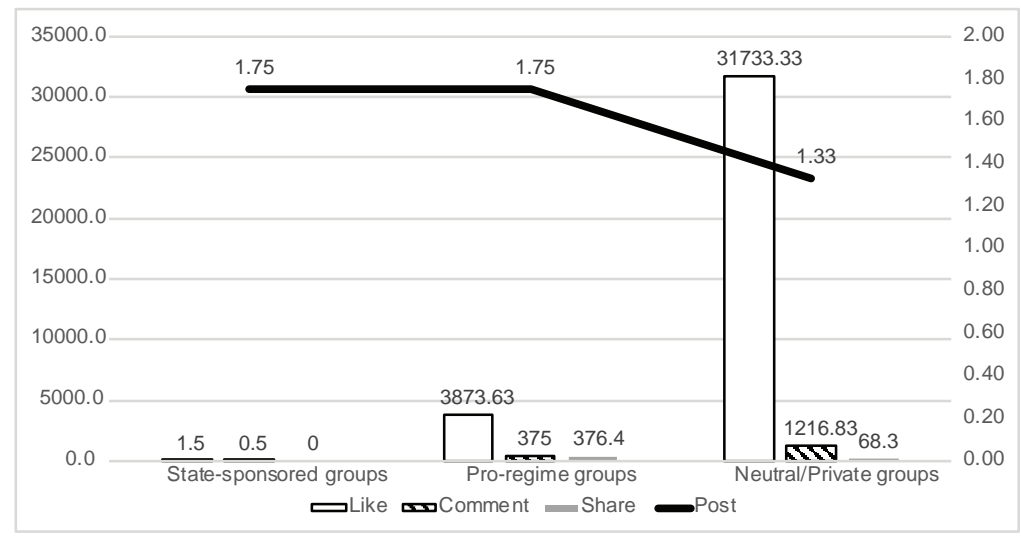

Source: Compiled by the author.

- Seen in such light, it smacks of elitism for the Western media to adopt a condescending tone to sneer at the pandemic-fighting model adopted by Vietnam and other countries and call it "draconian."

Those sentiments were reflected in an analysis of most-used keywords in all posts and comments on the eleven aforesaid Vietnamese Facebook groups as well as public responses on the Facebook page of the New Yorker magazine (Figure 8).

Western media have long come under fire for its "too narrow an agenda" when covering Africa, India or China; ${ }^{85}$ Vietnam has not been

${ }^{85}$ Daniel Griffiths, "The International Media Coverage of China: Too Narrow An Agenda?", Reuters Institute for the Study of Journalism, University of Oxford, 2013, https://reutersinstitute.politics.ox.ac.uk/sites/default/files/research/files/Th e\%2520international $\% 2520$ media $\% 2520$ coverage $\% 2520$ of $\% 2520$ China $\% 2520$ $\% 2520$ Too\%2520narrow\%2520an\%2520agenda.pdf 


\section{Figure 8: Keywords on Social Media Discussion on Vietnam's Patient 17 and the New Yorker article}

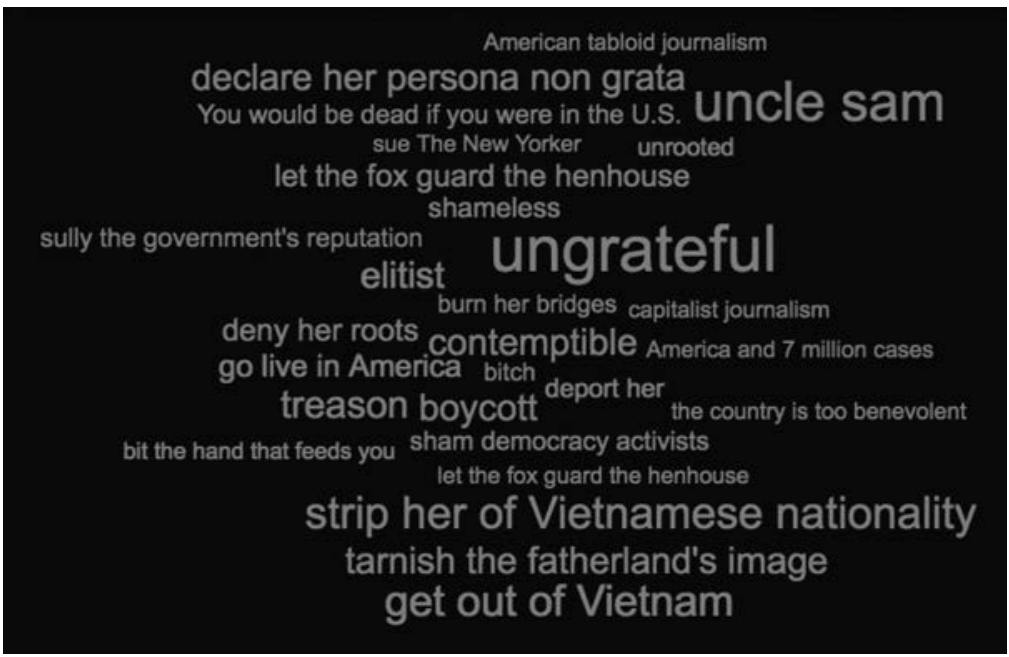

Source: Compiled by the author.

an exception. ${ }^{86}$ But that issue was not vigorously brought up in Vietnam's online sphere until the case of Patient 17, a move that was reflective of the exceptionally high public trust in the government, thanks to its success in battling the pandemic. One survey after the next corroborated public confidence in the government. For instance, in the State of Southeast Asia 2021 survey done by ISEAS - Yusof Ishak Institute-which included academics, government officials and business people - respondents from Vietnam registered the strongest approval for their government's handling of the pandemic. ${ }^{87}$ That success has been key to boosting patriotism and

\footnotetext{
${ }^{86}$ Hong Tien Vu, Nyan Lynn, "When the News Takes Sides: Automated Framing Analysis of News Coverage of the Rohingya Crisis by the Elite Press from Three Countries", Journalism Studies 21, no. 9 (2020): 1284-304.

${ }^{87}$ S. Seah et al., The State of Southeast Asia: 2021 (Singapore: ISEAS - Yusof Ishak Institute, 2021), https://www.iseas.edu.sg/wp-content/uploads/2021/01/ The-State-of-SEA-2021-v2.pdf
} 
nationalism in a population of nearly 100 million. But the online furore yet again proved short-lived and fleeting, lasting less than a week with no concrete action materializing in real life. Case in point: less than a month after the New Yorker article appeared, a Vietnamese researcher wrote an article in The Diplomat — an online magazine — to criticize its journalistic approach only to attract little public eyeballs. ${ }^{88}$

As shown in those three case studies, the triggers for expressions of nationalism revolved mostly around anti-China sentiments, territorial disputes, and geopolitical thinking. Another trigger emerged, however: Foreign criticism or scepticism of Vietnam's battle against the COVID-19 pandemic — and the sentiment against anti-Western superiority claimscould also galvanize online nationalists into action. It would be too preliminary, however, to conclude that this phenomenon will shape online Vietnamese nationalism in the long run. Another key takeaway is that online nationalists rarely exhibited any intent to translate their campaigns into real-life actions. They instead sought to alert the authorities and the public to certain issues by making as much noise online as they could. On the other side of the spectrum, state actors would strive to exploit and harness the confluence of nationalist sentiment and social media in order to serve various agendas.

All three case studies also prove that it is no longer rare for state and popular actors to find themselves in a situation in which their shared nationalist end goals of may cross paths and mutually reinforce. This leads to another major question: What roles have state actors played in shaping nationalist narratives?

\section{IMPLICATIONS FOR STATE ACTORS IN SHAPING NATIONALIST NARRATIVES}

Patterns of online nationalist mobilization crystallized the crucial role of pro-regime Facebook groups in flagging controversial issues, shaping nationalist narratives and propagating them. Even though their followings

${ }^{88}$ Vu Lam, "Public Shaming Is Terrible". 
pale in comparison with those of neutral/private groups, they are strong, active and persistent enough to peddle an online discourse in line with the regime's official line. Whether these groups have state backing is perhaps an evergreen question, for various reasons. First, the segment of online nationalists who are not state-backed and may be voluntarily participating in defending the state should never be undercounted and underestimated. Second, even though the authorities acknowledge the official existence of Force 47, the unit has been subject to widespread lampoon, criticism and backlash since its roll-out. Carrying the statesponsored designation is likely to aggravate public distaste, further discrediting the legitimacy of the narratives those Facebook groups seek to propagate. That may help to explain why state-sponsored Facebook groups have dismal followings and elicit little engagement. Lastly, even if pro-regime groups were linked to Force 47, not explicitly recognizing them could give the authorities some flexibility to play the public opinion card. The H\&M saga or the online backlash against Lee Hsien Loong were indicative of how the Vietnamese government could point to public feelings, even in cyberspace, to justify their actions and messages to China and the broader international audience. Given that, maintaining the status quo when it comes to the recognition of state-sponsored and pro-regime Facebook groups is likely to be the strategy of choice for the state apparatus.

Vietnamese authorities will also need to find suitable strategies to manage Vietnam's evolving social media ecosystem. Having tried for nearly a decade to exert greater control over the Internet and social media, they recognize that they cannot act like China and ban foreign tech giants altogether. They may have also realized that it is a tall order to build a domestic social networking site that can stand shoulder to shoulder with the likes of China's WeChat or Weibo ${ }^{89}$ Rather than crack down on Facebook, or try to elbow it out, the Vietnamese government look

\footnotetext{
89 "Vietnamese leader says banning social media sites impossible", Associated Press, 16 January 2015, https:/federalnewsnetwork.com/technology-main/2015/ 01/vietnamese-leader-says-banning-social-media-sites-impossible
} 
to co-opt and utilize the social media giant. In fact, in a country whose leaders once frowned upon it, Facebook has morphed from a perceived major threat into an increasingly handy accomplice for the authorities on various fronts. Vietnamese politicians, perhaps taking a page out of the censorship playbook adopted by authoritarians elsewhere, ${ }^{90}$ have become increasingly astute in exploiting Facebook to their advantage, utilizing it as a handy tool to gauge public sentiment, ${ }^{91}$ detect local corruption, ${ }^{92}$ spearhead disinformation campaign ${ }^{93}$ or squash dissenting voices. ${ }^{94}$ Even though Vietnam's cyber troops and public opinion shapers have been considered a more sophisticated extension of the traditional propaganda model, their modus operandi has still been largely governed by the ideological and political dos and don'ts that have long dictated the editorial line of the mass media. ${ }^{95}$ That is likely to leave the government's nationalism-boosting messages somewhat out of sync with the growing cadres of Internet-savvy youth in Vietnam. This leads to another Catch-22:

${ }^{90}$ Daniel Gayo-Avello, "Social Media and Authoritarianism", Social Science Research Network Electronic Journal (2015), https://dx.doi.org/10.2139/ ssrn. 2878705

${ }^{91}$ Dien Nguyen An Luong, "How Vietnam Has Borrowed from China's Online Censorship Playbook", South China Morning Post, 14 September 2020, https://www.scmp.com/week-asia/opinion/article/3101477/how-vietnam-hasborrowed-chinas-online-censorship-playbook

${ }^{92}$ Mai Thanh Truong, "Revisiting the Role of Social Media in the Dong Tam Land Dispute”, ISEAS Perspective, no. 2020/60, 10 June 2020.

93 "Facebook accuses telecoms groups of disinformation tactics". Financial Times, 12 February 2020. https://www.ft.com/content/1096ad54-4d5f-11 ea95a0-43d18ec715f5

${ }^{94}$ Rebecca Ratcliffle, "Facebook and Youtube Accused of Complicity in Vietnam Repression”, The Guardian, 1 December 2020, https://www.theguardian.com/ world/2020/dec/01/facebook-youtube-google-accused-complicity-vietnamrepression.

95 Giang Nguyen-Thu, "Vietnamese Media Going Social: Connectivism, Collectivism, and Conservatism”, Journal of Asian Studies 77, no. 4 (2018): 895-908. 
If the authorities move to make the most of the digital space to reach out to the young, any future attempt that seeks to tighten cyberspace could trigger a popular backlash. For Vietnam, that is an increasingly delicate balance to strike.

Over the years, Vietnamese authorities have also become well aware that any move to repress nationalism, anti-China sentiments in particular, can only further pit them against the public whose support they need to shore up. ${ }^{96}$ Conclusions of all case studies in this paper also show that issues that trigger anti-China sentiments-be it sovereignty or China's influence - can be most potent. That presents another major dilemma for Vietnamese authorities if they do not handle them well enough. While online nationalism started to manifest in Vietnam almost a decade behind that in China, leaders in both countries are well aware that online patriots have placed their pride first and foremost in their nations, and not necessarily in the regime. Both Chinese and Vietnamese authorities have also had to walk an increasingly blurry line between placating online nationalism and preventing it from turning against them. Case in point: On the heels of the 2014 oil rig crisis, sixty-one Vietnamese Communist Party members lodged an online petition calling for drastic reforms to reduce Hanoi's dependence on its giant northern neighbour and urging Vietnamese leaders to sue Beijing at an international tribunal. But on the other hand, the petition pulled no punches, calling on the leadership to jettison "the erroneous policies of building socialism and decisively veering towards a national and democratic direction" ${ }^{97}$ Also, if leveraging anti-China sentiments continues to be the strategy of choice by Hanoi to deal with Beijing, losing control of it is not the only risk. Doing so would be tantamount to playing with fire, as Wang and Womack point out: "Beijing had good reasons to be sceptical to the constraining power of an audience cost to Hanoi. Sharing a similar regime type and common

\footnotetext{
${ }^{96}$ Dien Nguyen An Luong, "How Hanoi is Leveraging Anti-China Sentiments Online”, ISEAS Perspective, no. 2020/115, 13 October 2020, p. 2.

${ }^{97}$ Wang and Womack, "Jawing through Crises".
} 
experiences dealing with nationalistic publics, Beijing understood Hanoi had means to deescalate the rhetoric and calm the public."98

\section{A FICKLE OR WIN-WIN PARTNERSHIP?}

As explained in this paper, the manifestations of online Vietnamese nationalism were mostly triggered by and tethered with entrenched visceral anti-China sentiments. Several large-scale anti-China demonstrations took place from early 2010 on a ferocious magnitude, triggering heavyhanded responses from the authorities, including physical repression. But in other cases that also revolved around anti-China sentiments since 2019 , nationalists confined themselves to the online sphere and showed no intent of mobilizing people in real life. They also proved how quickly online nationalistic campaigns could both galvanize and dissipate as both state and popular actors somehow achieved their end goals without stirring up any physical violence. If online Vietnamese nationalism continues to revolve around the most recent dynamic, toleration and responsiveness are likely to be the default response by the authorities. How the authorities have increasingly sought to exploit and harness online nationalist sentiments is a testament to this projection. Like their Chinese counterparts, Vietnamese leaders are probably well aware that in addition to the rising standards of living, nationalism remains a crucial part of the regime's legitimacy. ${ }^{99}$

The Vietnamese government's adept handling of the pandemic has also enabled it to inadvertently enlist the support of online nationalists who are not necessarily pro-regime under other circumstances. But this is where perhaps Vietnamese authorities are grappling with a vexing question: Is that type of online nationalism just a temporary phenomenon resulting from the pandemic, or is it a long-lasting one? This paper has highlighted several key examples where the online community has played

\footnotetext{
${ }^{98}$ Ibid.
}

${ }^{99} \mathrm{X} . \mathrm{Pu}$, "Book review: Jessica Chen Weiss, Powerful Patriots: Nationalist Protest in China's Foreign Relations". 
an increasingly proactive role as vigilantes against content they deem controversial, inappropriate or detrimental to Vietnam's image. On the other side of the spectrum, the authorities have repeatedly harped on the need to crack down on what they perceive to be anti-state content, which in their view has been chiefly one that is detrimental to the reputation of the leaders and the regime. ${ }^{100}$ Against that backdrop, how to justify cracking down on "anti-state content" without alienating the online vigilante force they need to enlist presents another daunting question for the authorities.

100 "Facebook Removes 159 Anti-State, Defamatory Accounts at Vietnam's Request", Tuoi Tre News, 23 December 2017, https:/tuoitrenews.vn/news/ business/20171223/facebook-removes-159-antistate-defamatory-accounts-atvietnams-request/43288.html 